UDK $630 * 52: 582.475(497.6)$

\title{
DEBLJINSKA I VISINSKA STRUKTURA JEDNODOBNIH ZASADA CRNOG BORA (Pinus nigra Arn.) NA KARBONATNIM SUPSTRATIMA U BOSNI
}

\author{
Diameter and height structures in even aged stands of \\ Austrian pine (Pinus nigra Arn.) on carbonate substrates in Bosnia
}

Aida Ibrahimspahic ${ }^{1}$, Besim Balic ${ }^{1}$, Ahmet Lojo ${ }^{1}$

\begin{abstract}
This paper analyzis the diameter and height structures of even aged stands of Austrian pine (Pinus nigra Arn.) on carbonate substrates in Bosnia of different age and site classes.

Average percentile distribution of numbers of trees based on diameter and height classes for the age classes of 10 years within particular site classes and their numerical parameters (average value, width of variability, standard deviation, coefficient of variability, kurtosis and skewness) were established.

The obtained results show the large variability in diameter and height of trees, that is, a strong differentiation of diameter and height of trees of tested stands.
\end{abstract}

Key words: even aged stands, Austrian pine (Pinus nigra Arn.), diameter structure, height structure.

\section{Izvod}

U radu se analiziraju debljinske i visinske strukture jednodobnih nenjegovanih šumskih zasada crnog bora različite starosti i uslova staništa na karbonatnim supstratima u Bosni. Utvrđene su prosječne procentualne raspodjele broja stabala po debljinskim i visinskim klasama za starosne klase širine 10 godina u okviru pojedinih bonitetnih razreda staništa i njihovi numerički parametri (aritmetička sredina, varijaciona širina, standardna devijacija, koeficijent varijacije, koeficijenti asimetrije i zaobljenosti). Dobijeni rezultati pokazuju veliki varijabilitet prečnika i visine stabala, odnosno intenzivno debljinsko i visinsko diferenciranje stabala ispitivanih zasada.

Ključne riječi: jednodobni zasadi, crni bor (Pinus nigra Arn.), debljinska struktura, visinska struktura.

\footnotetext{
${ }^{1}$ Šumarski fakultet Univerziteta u Sarajevu - Faculty of Forestry, University of Sarajevo
} 


\section{Debljinska $i$ visinska struktura jednodobnih zasada crnog bora (Pinus nigra Arn.) na karbonatnim supstratima $u$ Bosni}

\section{UVOD - Intoduction}

Proizvodnost i stabilnost šuma (sastojina), odnosno njihova efikasnost u ispunjavanju privrednih i ekoloških fukcija bitno zavise od njihovog stanja. Određeno stanje sastojina je rezultat dejstva brojnih faktora, prije svega karakteristika vrste ili vrsta drveća, starosti, uslova staništa i uzgojnih mjera, a ogleda se u strukturi sastojine.

Debljinska i visinska struktura jednodobnih sastojina su važniji pokazatelji strukture. Oblici ovih struktura indikatori su razvojnih faza jednodobnih sastojina i u dobroj mjeri mogu da ukažu na njihovo biološko stanje. Zbog toga se koriste za ocjenu pravilnosti razvoja, za objašnjenje djelovanja stanišnih uslova i uzgojnih mjera na rast i razvoj sastojina.

Cilj ovog rada je da se za nenjegovane zasade crnog bora na karbonatnim supstratima u Bosni utvrde debljinske i visinske strukture kao pokazatelji njihove strukturne izgrađenosti i na osnovu njih dođe do saznanja čime se (u prosjeku) karakterišu razvojne faze ovih zasada i kakvo je njihovo stanje pri različitim uslovima staništa.

\section{OBJEKT I METOD ISTRAŽIVANJA - Test study and methods}

Kroz duži vremenski period na prostorima Bosne i Hercegovine osnovani su brojni jednodobni šumski zasadi crnog bora, prvobitno pošumljavanjem ogoljenih površina, a u novije vrijeme i konverzijom izdanačkih šuma. Ovi zasadi su različite starosti, pojedinačno relativno male površine. Obično su udaljeni jedni od drugih i nisu njegovani. U najvećoj mjeri su zastupljeni u istočnoj Bosni, manje u zapadnoj i srednjoj, dok ih na sjeveru i jugu Bosne nema.

Istraživanja razvojnih, proizvodnih i strukturnih karakteristika ovih zasada, $\mathrm{s}$ ciljem postavljanja naučno utemeljenih taksacionih osnova za argumentovano planiranje i izvođenje gazdovanja, započeo je 1985. godine Šumarski fakultet u Sarajevu (PAVLIČ, 1999). Utvrđene su proizvodne i strukturne karakteristike ovih zasada u Hercegovini (MAUNAGA, 1994) i proizvodne karakteristike ovih zasada u Bosni (IBRAHIMSPAHIĆ, 2004).

Prema metodici premjera i registrovanja podataka u jednodobnim šumskim zasadima smrče, bijelog i crnog bora u BiH (PAVLIČ, 1999) u priodu od 1986. do 1990. godine postavljane su privremene ogledne plohe i prikupljeni predviđeni podaci. U zasadima crnog bora u Bosni, starim 10 i više godina, položeno je 156 oglednih ploha. Pri računskoj obradi podataka za 26 oglednih ploha utvrđena su relativno velika odstupanja te su one isključene iz istraživanja. U istraživanju su korišteni podaci prikupljeni na 130 oglednih ploha, pri čemu je taksacioni prag iznosio $0 \mathrm{~cm}$.

Pri planiranju uzorka vodilo se računa o njegovoj reprezentativnosti u pogledu najvažnijih faktora (geografski položaj, starost, visinski bonitet i sl.), te se na osnovu karakteristika uzorka može steći uvid u opšte i taksacione karakteristike objekta istraživanja. 
Zasadi crnog bora, kao i ostalih vrsta drveća u BiH intenzivno su se osnivali u periodu nakon II svjetskog rata, u manjoj mjeri u vrijeme monarhističke Jugoslavije, a sporadično i prije. Za zasade crnog bora na to ukazuje starosna struktura oglednih ploha (tabela 1.).

Tabela 1. Starosna struktura oglednih ploha

Table 1. Age Structure of sample plots

\begin{tabular}{|c|c|c|c|c|c|c|c|c|c|}
\hline $\begin{array}{c}\text { Klasa starosti } \\
\text { Age class }\end{array}$ & $\begin{array}{c}10- \\
20\end{array}$ & $\begin{array}{c}21- \\
30\end{array}$ & $\begin{array}{c}31- \\
40\end{array}$ & $\begin{array}{c}41- \\
50\end{array}$ & $\begin{array}{c}51- \\
60\end{array}$ & $\begin{array}{c}61- \\
70\end{array}$ & $\begin{array}{c}71- \\
80\end{array}$ & $\begin{array}{c}81- \\
90\end{array}$ & $\begin{array}{c}91- \\
100\end{array}$ \\
\hline $\begin{array}{c}\text { Broj ploha } \\
\text { Number of plots }\end{array}$ & 10 & 36 & 20 & 15 & 19 & 12 & 8 & 6 & 4 \\
\hline
\end{tabular}

S obzirom na nadmorsku visinu ogledne plohe su približno raspodijeljene prema klimapojasnom rasporedu vegetacije na sljedeći način:

- u pojasu šuma kitnjaka i običnog graba (400 - 700 m n.v.) $15 \%$,

- u pojasu šuma montane bukve (700 - 1000 m n.v.) $68 \%$,

- u pojasu šuma bukve, jele i smrče (1000 - 1300 m n.v.) $17 \%$.

$\mathrm{Na}$ osnovu strukture uzorka prema ekspoziciji može se reći da su najviše zastupljene južne ekspozicije (južna, jugoistočna i jugozapadna), oko $50 \%$, a s obzirom na nagib terena da su sa oko $70 \%$ zastupljeni nagibi manji od $20^{\circ}$ (tabela 2.).

Tabela 2. Struktura uzorka prema ekspoziciji i nagibu terena

Table 2. Sample structure based on exposition and slope

\begin{tabular}{|c|c|c|c|c|c|}
\hline $\begin{array}{c}\text { Ekspozicija } \\
\text { Exposition }\end{array}$ & $\begin{array}{c}\text { Broj ploha } \\
\text { Number of } \\
\text { plots }\end{array}$ & $\%$ & $\begin{array}{c}\text { Nagib } \\
\text { terena }\left({ }^{\circ}\right) \\
\text { Slope ( }\end{array}$ & $\begin{array}{c}\text { Broj ploha } \\
\text { Number of } \\
\text { plots }\end{array}$ & $\%$ \\
\hline Horizontal & 1 & 0,8 & $0-5$ & 10 & 7,7 \\
\hline $\mathrm{N}$ & 9 & 6,9 & $6-10$ & 26 & 20,0 \\
\hline $\mathrm{NE}$ & 16 & 12,3 & $11-15$ & 26 & 20,0 \\
\hline $\mathrm{E}$ & 8 & 6,2 & $16-20$ & 31 & 23,8 \\
\hline $\mathrm{SE}$ & 17 & 13,1 & $21-25$ & 20 & 15,4 \\
\hline $\mathrm{S}$ & 27 & 20,8 & $26-30$ & 9 & 6,9 \\
\hline $\mathrm{SW}$ & 28 & 21,5 & $31-35$ & 7 & 5,4 \\
\hline $\mathrm{W}$ & 12 & 9,2 & $36-40$ & 1 & 0,8 \\
\hline $\mathrm{NW}$ & 12 & 9,2 & - & - & - \\
\hline Total & 130 & 100,0 & Total & 130 & 100,0 \\
\hline
\end{tabular}

Prosječne veličine taksacionih elemenata uzorka pri istraživanju proizvodnih i strukturnih karakteristika jednodobnih zasada crnog bora prikazane su u sljedećoj tabeli. 
Tabela 3. Prosječne veličine taksacionih elemenata u uzorku

Table 3. Average values of taxative elements in sample plots

\begin{tabular}{|c|c|c|}
\hline $\begin{array}{c}\text { Taksacioni element } \\
\text { Taxative element }\end{array}$ & $\begin{array}{c}\text { Mjerna jedinica } \\
\text { Unit of measurement }\end{array}$ & $\begin{array}{c}\text { Prosječna veličina } \\
\text { Average value }\end{array}$ \\
\hline $\begin{array}{c}\text { Starost } \\
\text { Age }\end{array}$ & year & 44 \\
\hline $\begin{array}{c}\text { Bonitetni razred staništa } \\
\text { Site class }\end{array}$ & rang & 3 \\
\hline $\begin{array}{c}\text { Prosječna visina } \\
\text { Average height }\end{array}$ & $m$ & 13,1 \\
\hline $\begin{array}{c}\text { Gornja visina } \\
\text { Dominant height }\end{array}$ & $\mathrm{cm}$ & 14,1 \\
\hline $\begin{array}{c}\text { Srednji prečnik } \\
\text { Average diametar }\end{array}$ & - & 18,6 \\
\hline $\begin{array}{c}\text { Stepen zastrtosti } \\
\text { Canopy }\end{array}$ & trees/ha & 2533 \\
\hline $\begin{array}{c}\text { Broj stabala } \\
\text { Number of trees }\end{array}$ & $\mathrm{m}^{2} / \mathrm{ha}$ & 47,56 \\
\hline $\begin{array}{c}\text { Temeljnica } \\
\text { Basal area }\end{array}$ & $\mathrm{m}^{3} / \mathrm{ha}$ & 338,35 \\
\hline $\begin{array}{c}\text { Zapremina }(\geq 7 \mathrm{~cm}) \\
\text { Volume } \geq 7 \mathrm{~cm})\end{array}$ & $\mathrm{m}^{3} / \mathrm{ha} / \mathrm{god}$ & 10,76 \\
\hline $\begin{array}{c}\text { Zapreminski prirast }(\geq 7 \mathrm{~cm}) \\
\text { Volume increment }(\geq 7 \mathrm{~cm})\end{array}$ & & \\
\hline
\end{tabular}

Bonitetni razred staništa oglednih ploha ocjenjen je na osnovu dispozicije visinskih bonitetnih razreda staništa za nenjegovane zasade crnog bora u Bosni (IBRAHIMSPAHIĆ, 2004b).

S ciljem analiziranja debljinskih i visinskih raspodjela broja stabala zasada različite starosti i uslova staništa, ogledne plohe su razvrstane po bonitetnim razredima staništa i starosnim klasama širine 10 godina. Za svaku oglednu plohu broj stabala je, na osnovu površine ogledne plohe, izračunat za površinu od 1 ha ${ }^{1}$ i na osnovu tog broja izrađene su debljinske i visinske strukture za starosne klase u okviru svakog bonitetnog razreda staništa. Zbog grupisanja oglednih ploha po starosnim klasama, utvrđene strukture predstavljaju prosječnu raspodjelu broja stabala po debljinskim i visinskim klasama za pojedine starosne klase u okviru bonitetnih razreda staništa, naravno ako je u starosnoj klasi zastupljeno više od jedne plohe.

\footnotetext{
${ }^{1}$ Površina oglednih ploha se razlikuje za različite starosti, što je veća starost veća je površina ogledne plohe (PAVLIČ, 1999).
} 
Debljinska struktura je izrađena razvrstavanjem stabala na osnovu veličine prečnika na visini $1,3 \mathrm{~m} \mathrm{~s}$ korom $\mathrm{u}$ debljinske klase širine $2,5 \mathrm{~cm}$ za zasade mlađe od 40 godina, a za starije širina debljinskih klasa je $5 \mathrm{~cm}$. Uže debljinske klase su korištene za mlađe zasade zbog njihove manje varijacione širine, kako bi dobili veći broj klasa za koje izračunati pokazatelji mogu da daju realnu sliku strukture.

Pri izradi visinske strukture stabla svih starosnih klasa su grupisana u visinske klase širine $0,5 \mathrm{~m}^{1}$.

Udio stabala u pojedinim debljinskim i visinskim klasama iskazan je u procentualnom iznosu $\mathrm{i}$ za te veličine izračunati su koeficijenti asimetrije i zaobljenosti. Ostali numerički pokazatelji (srednji prečnik, varijaciona širina, standardna devijacija i varijacioni koeficijent) izračunati su za izvorne podatke uz upotrebu broja stabala na površini od 1 ha kao pondera (KOPRIVICA, 1997; EKINOVIĆ, 1997). Za provedena sortiranja i izračunavanje navedenih parametara korišten je softver MS Excel.

\section{REZULTATI I DISKUSIJA - Results and discussion}

Utvrđene prosječne procentualne debljinske i visinske strukture jednodobnih zasada crnog bora na karbonatnim supstratima u Bosni za pojedine starosne klase $\mathrm{u}$ okviru bonitetnih razreda staništa predstavljene su tabelarno u prilozima 1 i 2 , a numerički pokazatelji struktura u tabelama 4 i 5 . U prilozima je naveden broj oglednih ploha za koji su utvrđene strukture.

\section{Debljinska struktura - Diameter structure}

Prema podacima u prilogu 1, može se zaključiti da su debljinske strukture po obliku unimodalne, asimetrične, pri većoj starosti i boljim uslovima staništa pomjerene su ka višim debljinskim klasama. To se može bolje uočiti na grafički predstavljenim strukturama, te su na grafiku 1 predstavljene debljinske strukture za tri starosne klase (mlada, srednje stara i stara sastojina) uz prosječni bonitet staništa (grafik 1.a) i za tri različita boniteta staništa iste starosne klase (grafik 1.b).

Navedeno je u skladu sa teoretskim postavkama, raspodjela broja stabala po debljinskim stepenima jednodobnih sastojina je slična normalnoj Gausovoj raspodjeli (MATIĆ, 1980; PranJIĆ \& LUKIĆ, 1997; STAMENKović, VuČKOVIĆ, 1988). Međutim, precizniji opis debljinskih raspodjela na osnovu numeričkih parametara (tabela 4) pokazuje određena odstupanja od pravila.

\footnotetext{
${ }^{1} \mathrm{U}$ prilogu 2. visinska struktura je predstavljena za visinske klase širine $2 \mathrm{~m}$.
} 


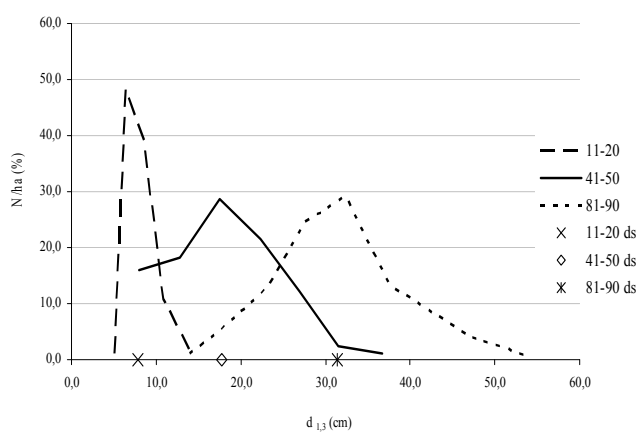

a) uticaj starosti, III bonitet

- influence of age, site class III

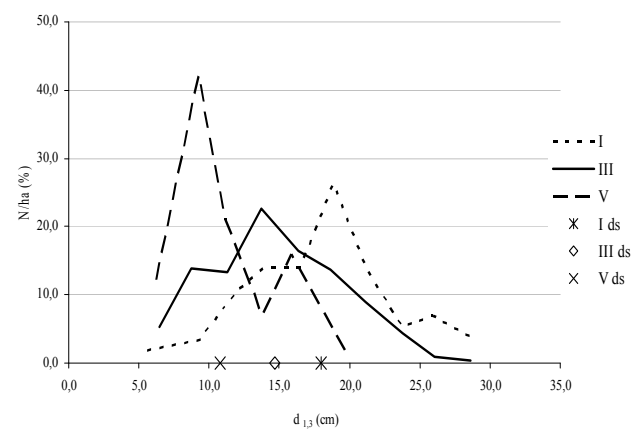

b) uticaj boniteta staništa, starosna klasa 31-40 - influence of site class, age class 31-40

Grafik 1. Procentualna prosječna debljinska struktura

Graph. 1. Percentile average diameter structure

Tabela 4. Numerički pokazatelji debljinske strukture

Table 4. Numerical parameters of diameter structure

\begin{tabular}{|c|c|c|c|c|c|c|c|c|c|c|}
\hline \multirow{2}{*}{$\begin{array}{c}\text { Bonitetni } \\
\text { razred } \\
\text { Site } \\
\text { class }\end{array}$} & \multirow{2}{*}{$\begin{array}{l}\text { Numerički } \\
\text { parametar } \\
\text { Numerical } \\
\text { parameter }\end{array}$} & \multicolumn{9}{|c|}{$\begin{array}{c}\text { Starosna klasa } \\
\text { Age class }\end{array}$} \\
\hline & & $10-20$ & 21-30 & $31-40$ & $41-50$ & $51-60$ & $61-70$ & 71-80 & $81-90$ & 91-100 \\
\hline 1 & 2 & 3 & 4 & 5 & 6 & 7 & 8 & 9 & 10 & 11 \\
\hline \multirow{8}{*}{ I } & $\bar{d}(\mathrm{~cm})$ & 10,60 & $12,15^{*}$ & 17,98 & - & - & - & - & - & - \\
\hline & $d_{\min }(\mathrm{cm})$ & 5,05 & 5,65 & 5,60 & - & - & - & - & - & - \\
\hline & $d_{\max }(\mathrm{cm})$ & 17,30 & $18,20^{*}$ & $29,50^{*}$ & - & - & - & - & - & - \\
\hline & Range $(\mathrm{cm})$ & 12,25 & 12,55 & 23,90 & - & - & - & - & - & - \\
\hline & $S_{d}(\mathrm{~cm})$ & 2,53 & 3,37 & 4,85 & - & - & - & - & - & - \\
\hline & $K_{v}(\%)$ & 23,90 & 27,78 & 26,96 & - & - & - & - & - & - \\
\hline & $\alpha_{3}$ & 0,11 & $-0,06$ & 0,07 & - & - & - & - & - & - \\
\hline & $\alpha_{4}$ & $-0,10$ & $-0,72$ & $-0,08$ & - & - & - & - & - & - \\
\hline \multirow{8}{*}{ II } & $\bar{d}(\mathrm{~cm})$ & 8,99 & $11,69^{*}$ & 17,22 & $17,19^{*}$ & 19,79 & $26,31^{*}$ & $23,59^{*}$ & - & 36,12 \\
\hline & $d_{\text {min }}(\mathrm{cm})$ & 5,10 & 5,10 & 5,05 & 7,75 & 6,15 & 12,15 & 6,50 & - & 16,70 \\
\hline & $d_{\max }(\mathrm{cm})$ & 15,10 & $24,03^{*}$ & 35,80 & $38,20^{*}$ & $35,40^{*}$ & $43,40^{*}$ & $40,05^{*}$ & - & 53,40 \\
\hline & Range $(\mathrm{cm})$ & 10,00 & 19,20 & 30,75 & 30,45 & 29,25 & 31,25 & 33,55 & - & 36,70 \\
\hline & $S_{d}(\mathrm{~cm})$ & 2,28 & 4,40 & 5,20 & 6,36 & 5,59 & 6,79 & 7,27 & - & 8,23 \\
\hline & $K_{v}(\%)$ & 25,37 & 37,62 & 30,21 & 37,01 & 28,23 & 25,80 & 30,80 & - & 22,79 \\
\hline & $\alpha_{3}$ & 0,61 & 0,60 & 0,34 & 0,97 & $-0,03$ & 0,00 & $-0,09$ & - & $-0,10$ \\
\hline & $\alpha_{4}$ & $-0,22$ & $-0,53$ & 0,16 & 0,56 & $-0,58$ & $-0,41$ & $-0,49$ & - & $-0,72$ \\
\hline
\end{tabular}




\begin{tabular}{|c|c|c|c|c|c|c|c|c|c|c|}
\hline 1 & 2 & 3 & 4 & 5 & 6 & 7 & 8 & 9 & 10 & 11 \\
\hline \multirow{8}{*}{ III } & $\bar{d}(\mathrm{~cm})$ & 7,82 & 12,26 & 14,72 & 17,86 & 18,54 & $24,77^{*}$ & 28,71 & 31,41 & - \\
\hline & $d_{\min }(\mathrm{cm})$ & 5,05 & 5,05 & 5,20 & 5,10 & 5,30 & 5,75 & 7,45 & 13,80 & - \\
\hline & $d_{\max }(\mathrm{cm})$ & 14,30 & 28,20 & 28,60 & 38,35 & 43,05 & $44,10^{*}$ & 50,65 & 53,70 & - \\
\hline & Range $(\mathrm{cm})$ & 9,25 & 23,15 & 23,40 & 33,25 & 37,75 & 38,35 & 43,20 & 39,90 & - \\
\hline & $S_{d}(\mathrm{~cm})$ & 1,61 & 4,11 & 4,70 & 6,55 & 6,24 & 7,67 & 8,31 & 7,50 & - \\
\hline & $K_{v}(\%)$ & 20,63 & 33,56 & 31,92 & 36,70 & 33,63 & 30,98 & 28,93 & 23,88 & - \\
\hline & $\alpha_{3}$ & 0,97 & 0,62 & 0,23 & 0,21 & 0,25 & $-0,07$ & $-0,43$ & 0,32 & - \\
\hline & $\alpha_{4}$ & 0,99 & 0,04 & $-0,50$ & $-0,45$ & $-0,39$ & $-0,27$ & 0,17 & 0,09 & - \\
\hline \multirow{8}{*}{ IV } & $\bar{d}(\mathrm{~cm})$ & - & 11,35 & 12,44 & 14,04 & 17,58 & $25,75^{*}$ & $25,35^{*}$ & 27,41 & - \\
\hline & $d_{\min }(\mathrm{cm})$ & - & 5,05 & 5,10 & 5,50 & 7,20 & 6,75 & 6,75 & 10,50 & - \\
\hline & $d_{\max }(\mathrm{cm})$ & - & 23,00 & 21,90 & 31,95 & 32,40 & $43,30^{*}$ & 46,45 & $42,15^{*}$ & - \\
\hline & Range $(\mathrm{cm})$ & - & 17,95 & 16,80 & 26,45 & 25,20 & 36,55 & 39,70 & 31,65 & - \\
\hline & $S_{d}(\mathrm{~cm})$ & - & 3,31 & 3,61 & 4,66 & 4,54 & 7,55 & 8,13 & 8,75 & - \\
\hline & $K_{v}(\%)$ & - & 29,16 & 28,98 & 30,96 & 25,83 & 29,32 & 32,06 & 31,92 & - \\
\hline & $\alpha_{3}$ & - & 0,31 & 0,44 & 0,29 & 0,41 & 0,08 & 0,09 & $-0,32$ & - \\
\hline & $\alpha_{4}$ & - & $-0,15$ & 0,22 & $-0,15$ & $-0,12$ & 0,04 & $-0,23$ & $-0,97$ & - \\
\hline \multirow{8}{*}{$\mathrm{V}$} & $\bar{d}(\mathrm{~cm})$ & - & 9,83 & 10,81 & - & - & 27,90 & - & $24,10^{*}$ & - \\
\hline & $d_{\min }(\mathrm{cm})$ & - & 5,45 & 5,15 & - & - & 12,60 & - & 12,90 & - \\
\hline & $d_{\max }(\mathrm{cm})$ & - & 18,45 & 19,70 & - & - & 45,65 & - & $43,40^{*}$ & - \\
\hline & Range $(\mathrm{cm})$ & - & 13,00 & 14,55 & - & - & 33,05 & - & 30,50 & - \\
\hline & $S_{d}(\mathrm{~cm})$ & - & 2,73 & 3,11 & - & - & 8,29 & - & 7,76 & - \\
\hline & $K_{v}(\%)$ & - & 27,73 & 28,79 & - & - & 29,72 & - & 32,33 & - \\
\hline & $\alpha_{3}$ & - & 0,56 & 0,69 & - & - & 0,24 & - & 0,67 & - \\
\hline & $\alpha_{4}$ & - & $-0,31$ & $-0,08$ & - & - & $-0,34$ & - & $-0,51$ & - \\
\hline
\end{tabular}

Može se primijetiti da je donja granica intervala variranja prečnika stabala $\left(d_{\min }\right)$ relativno niska i bitno se ne mijenja sa starošću i bonitetom staništa, a za gornju granicu $\left(d_{\max }\right)$ da je u pojedinim slučajevima veća za mlađe sastojine i lošije uslove staništa u odnosu na starije i bolje uslove staništa ${ }^{1}$ što nije u skladu sa pravilima.

U vezi s tim, i za veličine utvrđenih numeričkih parametara strukture javila su se određena odstupanja od pravila. Srednji prečnik, varijaciona širina i standradna devijacija nisu u svim slučajevima veći pri većoj starosti i boljim uslovima staništa. Koeficijent varijacije nepravilno varira u intervalu približno od 20 do $35 \%$.

\footnotetext{
${ }^{1}$ U tabeli 4 veličine srednjih prečnika i maksimalnih prsnih prečnika stabala koji su manji u starijoj dobi za isti bonitet staništa ili pri boljim uslovima staništa u odnosu na lošije za istu starosnu klasu obilježene su zvjezdicom $\left({ }^{*}\right)$.
} 


\section{Debljinska i visinska struktura jednodobnih zasada crnog bora (Pinus nigra Arn.) na karbonatnim supstratima u Bosni}

I u pogledu asimetrije i zaobljenosti struktura uočavaju se odstupanja od pravila. Debljinske strukture za pojedine starosne klase i bonitete staništa nisu zaobljene. Za neke je utvrđena nešto jača asimetrija nego što bi trebala biti, a za pojedine više starosne klase utvrđena je pozitivna asimetrija umjesto negativne ili odsustva asimetrije.

Prisustvo stabala u nižim debljinskim klasama kroz duži vremenski period, kojih po pravilu ne bi trebalo biti, dijelom se može objasniti sposobnošću crnog bora, u biti vrste svjetla, da se pri boljim uslovima staništa, kakva su staništa na kojima su osnivani predmetni zasadi (IBRAHIMSPAHIĆ, 2004a), ponaša kao vrsta polusjene (PINTARIĆ, 2002), pa određen broj stabala koja zaostaju u razvoju ipak preživljava.

Prema ovom, asimetrija debljinskih struktura starijih zasada treba da bude negativna i to jako negativna. Međutim, to nije utvrđeno u svim slučajevima, čak je za neke utvrđeno suprotno. Za ove slučajeve, pozitivna asimetrija ili njeno odsustvo može da bude posljedica male zastupljenosti ili nezastupljenosti stabala u višim debljinskim klasama.

Ovom $u$ prilog idu utvrđena odstupanja $u$ pogledu varijacione širine debljinskih struktura, odnosno njihove gornje granice. Mala zastupljenost stabala $u$ višim debljinskim, a vjerovatno i višim visinskim klasama može da bude još jedan od razloga zbog kojeg se u sastojinama mogu dugo zadržati stabla podređenog položaja. U tim slučajevima u unutrašnjosti sastojina je više svjetlosti što omogućava opstanak stabala podređenog položaja.

\section{Visinska struktura - Height structure}

Visinske strukture predmetnih zasada (prilog 2, grafik 2) su, kao i debljinske po obliku unimodalne, asimetrične, pri većoj starosti i boljim uslovima staništa pomjerene ka višim debljinskim klasama, što je u skladu sa teroteskim postavkama (MATIĆ, 1980; PRANJIĆ \& LUKIĆ, 1997; STAMENKOVIĆ, VuČKOVIĆ 1988).

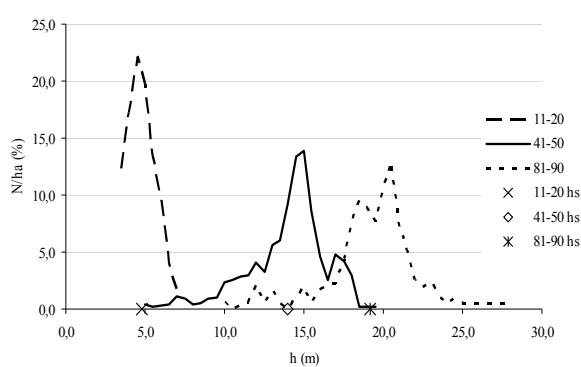

a) uticaj starosti, III bonitet

- influence of age, site class III

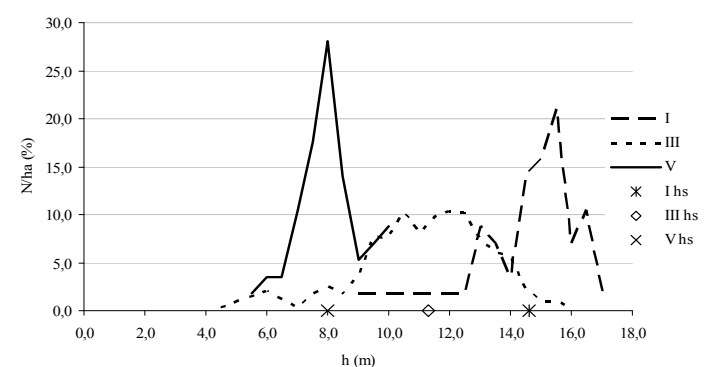

b) uticaj boniteta staništa, starosna klasa 31-40 - influence of site class, age class 31-40

Grafik 2. Procentualna prosječna visinska struktura

Graph. 2. Percentile average height structure 
Numerički pokazatelji visinske strukture pojedinih starosnih klasa u okviru bonitetnih razreda staništa (tabela 5), kao i za debljinske strukture (tabela 4), ukazuju na odstupanja od pravila.

Tabela 5. Numerički pokazatelji visinske strukture

Table 5. Numerical parameters of height structure

\begin{tabular}{|c|c|c|c|c|c|c|c|c|c|c|}
\hline \multirow{2}{*}{$\begin{array}{c}\text { Bonitetni } \\
\text { razred } \\
\text { Site } \\
\text { class }\end{array}$} & \multirow{2}{*}{$\begin{array}{l}\text { Numerički } \\
\text { parametar } \\
\text { Numerical } \\
\text { parameter }\end{array}$} & \multicolumn{9}{|c|}{$\begin{array}{c}\text { Starosna klasa } \\
\text { Age class }\end{array}$} \\
\hline & & $10-20$ & $21-30$ & $31-40$ & $41-50$ & $51-60$ & $61-70$ & $71-80$ & $81-90$ & $91-100$ \\
\hline$I$ & 2 & 3 & 4 & 5 & 6 & 7 & 8 & 9 & 10 & $\frac{11}{11}$ \\
\hline \multirow{8}{*}{ I } & $\bar{h}(m)$ & 6,20 & $9,08^{*}$ & 14,55 & - & - & - & - & - & - \\
\hline & $h_{\min }(m)$ & 3,50 & 5,00 & 9,00 & - & - & - & - & - & - \\
\hline & $h_{\max }(m)$ & 8,00 & $11,50^{*}$ & $17,00^{*}$ & - & - & - & - & - & - \\
\hline & Range (m) & 4,50 & 6,50 & 8,00 & - & - & - & - & - & - \\
\hline & $S_{d}(m)$ & 1,01 & 1,48 & 1,65 & - & - & - & - & - & - \\
\hline & $K_{v}(\%)$ & 16,22 & 16,30 & 11,36 & - & - & - & - & - & - \\
\hline & $\alpha_{3}$ & $-0,35$ & $-0,88$ & $-1,32$ & - & - & - & - & - & - \\
\hline & $\alpha_{4}$ & $-0,29$ & 0,70 & 1,91 & - & - & - & - & - & - \\
\hline \multirow{8}{*}{ II } & $\bar{h}(m)$ & 5,59 & 9,78 & 13,25 & 17,46 & $17,08^{*}$ & 20,41 & $19,75^{*}$ & - & 22,07 \\
\hline & $h_{\min }(m)$ & 3,00 & 4,00 & 5,00 & 5,00 & 6,50 & 6,50 & 6,00 & - & 13,00 \\
\hline & $h_{\max }(m)$ & 8,00 & 13,50 & 17,50 & 22,50 & $21,50^{*}$ & 24,50 & $24,50^{*}$ & - & 27,50 \\
\hline & Range (m) & 5,00 & 9,50 & 12,50 & 17,50 & 15,00 & 18,00 & 18,50 & - & 14,50 \\
\hline & $S_{d}(m)$ & 1,34 & 2,01 & 2,20 & 2,58 & 2,45 & 2,54 & 2,78 & - & 2,73 \\
\hline & $K_{v}(\%)$ & 23,91 & 20,57 & 16,63 & 14,80 & 14,36 & 12,43 & 14,07 & - & 12,37 \\
\hline & $\alpha_{3}$ & $-0,26$ & $-0,04$ & $-0,94$ & $-1,64$ & $-1,50$ & $-2,48$ & $-2,38$ & - & $-0,89$ \\
\hline & $\alpha_{4}$ & $-1,14$ & $-0,68$ & 1,56 & 4,65 & 3,19 & 9,33 & 7,87 & - & 0,83 \\
\hline \multirow{8}{*}{ III } & $\bar{h}(m)$ & 4,79 & 8,74 & 11,31 & 13,99 & 15,23 & 17,42 & 17,64 & 19,17 & - \\
\hline & $h_{\min }(m)$ & 3,50 & 3,00 & 4,50 & 5,00 & 4,50 & 4,00 & 5,00 & 10,00 & - \\
\hline & $h_{\max }(m)$ & 7,00 & 15,00 & 16,00 & 19,50 & 20,50 & 23,00 & $22,00^{*}$ & 28,00 & - \\
\hline & Range (m) & 3,50 & 12,00 & 11,5 & 14,50 & 16,00 & 19,00 & 17,00 & 18,00 & - \\
\hline & $S_{d}(m)$ & 0,86 & 1,68 & 1,97 & 2,47 & 2,92 & 3,11 & 3,62 & 2,66 & - \\
\hline & $K_{v}(\%)$ & 18,06 & 19,18 & 17,38 & 17,62 & 19,18 & 17,85 & 20,54 & 13,87 & - \\
\hline & $\alpha_{3}$ & 0,39 & $-0,18$ & $-0,47$ & $-0,91$ & $-0,97$ & $-1,82$ & $-2,10$ & $-0,77$ & - \\
\hline & $\alpha_{4}$ & $-0,50$ & 0,42 & 0,37 & 1,12 & 0,75 & 4,47 & 4,15 & 1,77 & - \\
\hline
\end{tabular}




\begin{tabular}{|c|c|c|c|c|c|c|c|c|c|c|}
\hline 1 & 2 & 3 & 4 & 5 & 6 & 7 & 8 & 9 & 10 & 11 \\
\hline \multirow{8}{*}{ IV } & $\bar{h}(m)$ & - & $7,10^{*}$ & 9,98 & 11,52 & 13,90 & 14,26 & 14,87 & 17,53 & - \\
\hline & $h_{\min }(m)$ & - & 3,50 & 5,00 & 6,00 & 6,00 & 7,00 & 6,00 & 10,00 & - \\
\hline & $h_{\max }(m)$ & - & 11,50 & 14,00 & 15,50 & 17,50 & 17,50 & 19,00 & 21,00 & - \\
\hline & Range (m) & - & 8,00 & 9,00 & 9,50 & 11,50 & 10,50 & 13,00 & 11,00 & - \\
\hline & $S_{d}(m)$ & - & 1,35 & 1,61 & 1,61 & 2,23 & 1,82 & 2,84 & 2,46 & - \\
\hline & $K_{v}(\%)$ & - & 19,01 & 16,10 & 14,01 & 16,01 & 12,76 & 19,06 & 14,00 & - \\
\hline & $\alpha_{3}$ & - & 0,21 & $-0,38$ & $-0,76$ & $-1,22$ & $-0,88$ & $-1,24$ & $-1,05$ & - \\
\hline & $\alpha_{4}$ & - & $-0,18$ & 0,94 & 1,04 & 1,36 & 1,39 & 1,02 & 0,66 & - \\
\hline \multirow{9}{*}{$\mathrm{V}$} & $\bar{h}(m)$ & - & 7,45 & 8,04 & - & - & 12,65 & - & 13,75 & - \\
\hline & $h_{\min }(m)$ & - & 5,00 & 5,50 & - & - & 8,00 & - & 7,50 & - \\
\hline & $h_{\max }(m)$ & - & 10,50 & 10,00 & - & - & 20,50 & - & $19,50^{*}$ & - \\
\hline & Range (m) & - & 5,50 & 4,50 & - & - & 12,50 & - & 12,00 & - \\
\hline & $S_{d}(m)$ & - & 1,33 & 1,04 & - & - & 2,44 & - & 3,50 & - \\
\hline & $K_{v}(\%)$ & - & 17,82 & 12,88 & - & - & 19,33 & - & 25,47 & - \\
\hline & $\alpha_{3}$ & - & 0,21 & 0,06 & - & - & 1,09 & - & $-0,13$ & - \\
\hline & $\alpha_{4}$ & - & $-0,95$ & $-0,10$ & - & - & 2,08 & - & $-1,25$ & - \\
\hline & $\alpha_{4}$ & - & $-0,31$ & $-0,08$ & - & - & $-0,34$ & - & $-0,51$ & - \\
\hline
\end{tabular}

Donja granica intervala variranja visine stabala $\left(h_{\text {min }}\right)$, kao i za debljinsku strukturu, relativno je niska i ne mijenja se bitno sa starošću i bonitetom staništa, a u pojedinim slučajevima gornja granica $\left(h_{\max }\right)$ je u mlađoj dobi i pri lošijim uslovima staništa veća u odnosu na stariju dob i bolje uslove staništa ${ }^{1}$.

Varijaciona širina i standardna devijacija u okviru istog boniteta staništa uglavnom se sa starošću povećavaju, dok u okviru iste starosne klase za različite bonitete staništa nepravilno variraju. Koeficijent varijacije varira u intervalu približno od 10 do $25 \%$, nepravilno za različite bonitete staništa i istu klasu starosti, a u okviru istog boniteta staništa sa starošću se uz izuzetke smanjuje.

Ovi parametri visinskih struktura ne ukazuju na koncentraciju visine stabala oko prosječne visine sa starošću sastojine, što je u suprotnosti sa pravilima razvoja visinske strukture. Po pravilu, sa starošću sastojine u borbi za opstanak slabija stabla odumiru dok jača intenzivno prirašćuju u visinu, te je njihova visina bliska prosječnoj, varijaciona širina se smanjuje, a negativna asimetrija se ublažava i na kraju prelazi $u$

\footnotetext{
${ }^{1}$ U tabeli 5 prosječne visine i maksimalne visine stabala koje su manje u starijoj dobi za isti bonitet staništa ili pri boljim uslovima staništa u odnosu na lošije za istu starosnu klasu obilježene su zvjezdicom $\left(^{*}\right)$.
} 
pozitivnu. Od ovih pravila odstupa i utvrđena negativna asimetrija ovih struktura koja je izraženija u starijoj dobi.

Razlozi ovih odstupanja od teoretskih postavki su isti kao i za odstupanja debljinskih struktura. U sastojinama se kroz duži vremenski period zadržavaju stabla u podređenom položaju zahvaljujući sposobnosti crnog bora da podnese zasjenjivanje, dobrim uslovima staništa i većoj količini svjetlosti u sastojinama sa „nedostatkom“ stabala u višim debljinskim i visinskim klasama.

U borbi za opstanak, prije svega u borbi za svjetlošću, posebno gdje je veliki broj stabala na jedinici površine, stabla intenziviraju prirašćivanje u visinu, nekad i na račun prirasta u debljinu, pa se razvijaju vitka stabla koja su neotporna na prelome. Upravo prelamanje stabala viših debljinskih i visinskih klasa može da bude razlog nedostatka stabala u ovim klasama ili eventualne sječe.

Stabla nižih debljinskih i visinskih klasa koja su zastupljena u starijim sastojinama potištena su, vjerovatno devitalizovana, u prirastu sastojine učestvuju neznatno, najveći dio proizvedene organske materije troše za obavljanje svojih životnih funkcija, pa u procesu disanja oslobađaju veću količinu $\mathrm{CO}_{2}$ od količine koju troše u procesu asimilacije. U mlađoj dobi, kada su sva stabla u približno istim uslovima za rast i razvoj, ova stabla su konkurenti i ometaju rast i razvoj stabala većeg produkcionog potencijala. Osim ovoga, potištena stabla u sastojinama osnovanim na staništima drugih vrsta drveća, gdje se obično javlja podmladak tih vrsta drveća, ometaju njegov pravilan razvoj. Na osnovu prethodnog može se reći da su ova stabla nepoželjna u sastojini i sa produkcionog i sa ekološkog aspekta.

\section{ZAKLJUČNA RAMATRANJA - Conclusions}

Cilj ovog rada je da se za nenjegovane zasade crnog bora na karbonatnim supstratima u Bosni, različite starosti i uslova staništa, na osnovu debljinske i visinske strukture ocijeni stanje ovih zasada.

Debljinske strukture su unimodalne, zaobljene i uz izuzetke u mlađoj dobi pozitivno asimetrične sa manjom varijacionom širinom, a u starijoj dobi negativno asimetrične sa većom varijacionom širinom. Visinske strukture su unimodalne i uglavnom negativno asimetrične, sa većom varijacionom širinom i negativnom asimetrijom u starijoj dobi. Za obje strukture je karakteristično neznatno pomjeranje donje granice intervala variranja ovih struktura sa starošću, a za pojedine slučajeve nedostatak stabala u višim klasama.

Pri boljim uslovima staništa debljinske i visinske strukture su pomjerene ka višim klasama. Debljinske strukture se karakterišu većom varijacionom širinom, a u pogledu ostalih numeričkih pokazatelja uticaj boniteta staništa nije se jasno ispoljio.

Dobijeni rezultati ukazuju na određena odstupanja razvoja predmetnih zasada od pravila razvoja jednodobnih sastojina. Utvrđeno jako debljinsko i visinsko diferenciranje stabala, a u pojedinim slučajevima nedostatak dominantnih stabala, razlozi su za ova odstupanja od pravila. S obzirom da je intenzivno diferenciranje stabala karakteristično za nenjegovane zasade, može se zaključiti da je do izražaja 


\section{Debljinska $i$ visinska struktura jednodobnih zasada crnog bora (Pinus nigra Arn.) na karbonatnim supstratima u Bosni}

došao uticaj izostalih mjera njege, pa se zasadi razvijaju na način karakterističan za nenjegovane sastojine. U takvim sastojinama diferenciranje stabala se odvija po zakonima prirode - ugibaju slabija stabla, preživljavaju otpornija, koja se ne moraju odlikovati velikom produktivnošću i dobrim kvalitetom, stabla su u prostoru nepravilano raspoređena.

Osim uticaja izostalih mjera njege, utvrđeno stanje predmetnih zasada može se pripisati i uticaju dobrih uslova staništa na kojima su osnovani te sposobnosti crnog bora da pri dobrim stanišnim uslovima stabla podnose zasjenjivanje i konkurenciju.

$\mathrm{Na}$ osnovu utvrđenih rezultata može se zaključiti da bez obzira na dobre uslove staništa i tolerantnost crnog bora predmetni zasadi nisu dobrog stanja i da su osnovni uzrok za to izostale mjere njege. Naime, blagovremenom primjenom adekvatnog uzgojnog tretmana iz sastojina se uklanjaju „nepoželjna“ stabla i time potpomaže pravilan rast i razvoj stabala većeg produkcionog potencijala i boljeg kvaliteta, realizuje dio prinosa koji u suprotnom uglavnom predstavlja mortalitet i u krajnoj liniji postiže pravilan rast i razvoj sastojina a koji je u skladu sa sposobnošću sastojina da trajno ispunjavaju brojne funkcije.

\section{LITERATURA - Reference}

IBRAHIMSPAHIĆ, A. (2004a): Regresione analize proizvodnih karakteristika jednodobnih nenjegovanih šumskih zasada crnog bora (Pinus nigra Arn.) na karbonatnim supstratima u Bosni. Magistarski rad. Šumarski fakultet u Sarajevu.

IBRAHIMSPAHIĆ, A. (2004b): Izrada dispozicije bonitetnih razreda staništa jednodobnih zasada crnog bora (Pinus nigra Arn.) na karbonatnim supstratima u Bosni. Radovi Šumarskog fakulteta Univerziteta u Sarajevu, No 1- knjiga XXXIV.

EKINOVIĆ, S. (1997): Metode statističke analize u Microsoft Exscel-u. Mašinski fakultet u Zenici. Univerzitet u Sarajevu.

KoPRIVICA, M. (1997): Šumarska biometrika, knjiga I. Institut za šumarstvo, Beograd.

MATIĆ, V. (1980): Prirast i prinos šuma, udžbenik. Šumarski fakultet Univerziteta u Sarajevu.

PAVLIČ, J. (1999): Metodika premjera i registrovanja podataka u jednodobnim zasadima smrče (Picea abies Karst.), bijelog bora (Pinus sylvestris L.) i crnog bora (Pinus nigra Arn.) u Bosni i Hercegovini. Radovi Šumarskog fakulteta Univerziteta u Sarajevu, No 1- knjiga XXIX.

PINTARIĆ, K. (2002): Šumsko-uzgojna svojstva i život važnijih vrsta šumskog drveća. Udruženje šumarskih inženjera i tehničara Federacije Bosne i Hercegovine.

PRANJIĆ, A. \& LUKIĆ, N. (1997): Izmjera šuma, udžbenik. Šumarski fakultet Sveučulišta u Zagrebu.

StAmENKović, V. \& VuČKović, M. (1988): Prirast i proizvodnost stabala i šumskih sastojina, udžbenik. Šumarski fakultet Univerziteta u Beogradu. 


\section{Summary}

Diameter and height structures of untreated even aged stands of Austrian pine (Pinus nigra Arn.) on carbonate substrates in Bosnia were used to assess their status. Data were collected from 130 sample plots in spatial distribution of these stands. Numerical parameters of these structures (average value, width of variability, standard deviation, coefficient of variability, skewness and kurtosis) were analyzed.

Diameter structures are unimodal, rounded and with exceptions they are positively asymmetric with less width variations in younger age and negatively asymmetric with greater width variations in older age. Height structures are unimodal and generally negatively asymmetric with greater width variations and negatively asymmetry in old age. A slight shift of lower limits of interval variations is characteristic for these structures as they age and in some cases of lack of trees in the higher classes. Diameter and height structure were moved to higher classes and diameter structure is characterized by a greater width of variations in better site conditions while the influence of site condition on the other numerical parameters is not clearly expressed.

The obtained results show some deviations from the rules of development of the even-aged stands. The established differentiation of diameter and height of trees and in some cases the lack of dominant trees can be attributed to the influence of good site conditions. The ability of Austrian pine trees to sustain shading and competition in good site conditions can also be credited to the sites, even if there was no adequate treatment. 


\begin{tabular}{|c|c|c|c|c|c|c|c|c|c|c|c|c|c|c|c|c|c|c|c|c|}
\hline & & $\| \simeq$ & $\begin{array}{ll}1 & 0 \\
i & 0 \\
\pi & n \\
m & n\end{array}$ & & & & $\begin{array}{cc}1 & 0 \\
i & n \\
n & n \\
m & n\end{array}$ & & & సิ. & $\begin{array}{cc}1 & 0 \\
8 & 0 \\
0 & 0\end{array}$ & & & & & & $\begin{array}{cc}1 & 0 \\
n & n \\
n & n \\
n & n\end{array}$ & & & \\
\hline & & $\because$ & $\begin{array}{ll}1 & n \\
0 & n \\
e & n\end{array}$ & & & & $\begin{array}{cc}1 & n \\
\dot{0} & \tilde{n} \\
m & n\end{array}$ & & & $\begin{array}{l}\infty \\
n \\
0 \\
0\end{array}$ & $\begin{array}{cc}1 & 0 \\
& 0 \\
n & 0\end{array}$ & & & & & & $\begin{array}{cc}1 & n \\
0 & n \\
m & n\end{array}$ & & & \\
\hline 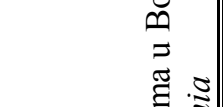 & & \pm & $\begin{array}{ll}1 & 0 \\
\hat{N} & 0 \\
\hat{N} & 0\end{array}$ & & & $\begin{array}{l}\bar{n} \\
m\end{array}$ & $\begin{array}{ll}1 & 0 \\
\hat{N} & 0 \\
& 0\end{array}$ & & & 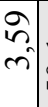 & \begin{tabular}{ll}
1 & 0 \\
\hdashline & 0 \\
$n$ & $n$
\end{tabular} & & & & & $\frac{\sigma}{f}$ & $\begin{array}{cc}\dot{1} & 0 \\
\hat{N} & 0 \\
& 0\end{array}$ & & & \\
\hline 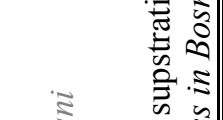 & & $\because$ & \begin{tabular}{ll}
1 & $n$ \\
& \multirow{2}{*}{}
\end{tabular} & & & 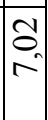 & \begin{tabular}{ll}
$\dot{1}$ & $n$ \\
& \multirow{2}{*}{}
\end{tabular} & & & $\begin{array}{l}\text { ले } \\
\text { mे. }\end{array}$ & \begin{tabular}{cc}
1 & 0 \\
\hdashline & 0 \\
7 & 0
\end{tabular} & & & & & $\begin{array}{l}0 \\
: \\
\pm \\
\pm\end{array}$ & 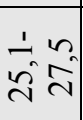 & & $\hat{n}$ & O \\
\hline 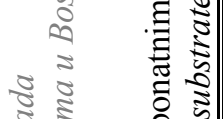 & 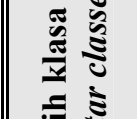 & $\simeq$ & 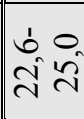 & & & 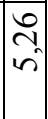 & $\begin{array}{ll}b & 0 \\
\text { N } & n \\
& 0\end{array}$ & & 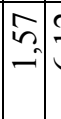 & $\begin{array}{l}7 \\
6 \\
6\end{array}$ & \begin{tabular}{cc|}
1 & 0 \\
0 & 0 \\
& 5
\end{tabular} & & & $\mid \begin{array}{c}\hat{\infty} \\
-1\end{array}$ & & $\begin{array}{l}0 \\
0 \\
\pm \\
\pm\end{array}$ & 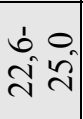 & & $\begin{array}{l}\infty \\
a \\
0\end{array}$ & $\vec{f}$ \\
\hline 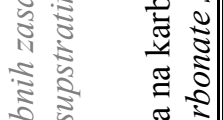 & $\frac{0}{0}$ & $=$ & 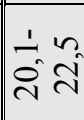 & & & $\begin{array}{l} \\
\text { I } \\
\pm\end{array}$ & 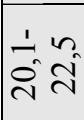 & & $\begin{array}{l} \pm \\
m^{\prime}\end{array}$ & $\begin{array}{l}0 \\
\text { aे } \\
\text { m. }\end{array}$ & $\begin{array}{cc}1 & 0 \\
& 0 \\
m & 0\end{array}$ & $\underset{\sim}{\infty}$ & \begin{tabular}{|c|}
$\infty$ \\
$m$ \\
0 \\
0
\end{tabular} & $\begin{array}{l}\mid \\
b \\
a\end{array}$ & $\begin{array}{ll}m & \delta \\
m & \\
n & \end{array}$ & â. & 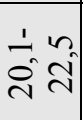 & & \begin{tabular}{|c|} 
\\
0 \\
$m$
\end{tabular} & $\begin{array}{l}+ \\
\infty \\
\infty\end{array}$ \\
\hline 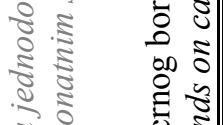 & 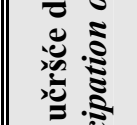 & 이 & 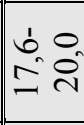 & & 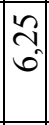 & $\begin{array}{l}\mathcal{N} \\
\tilde{2} \\
0 \\
\sim\end{array}$ & 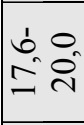 & & $\begin{array}{l}\alpha \\
\infty \\
6 \\
6\end{array}$ & 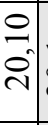 & \begin{tabular}{cc}
1 & 0 \\
\hdashline & 0 \\
$m$ & $n$
\end{tabular} & $\begin{array}{l}\text { Z } \\
\dot{f} \\
\end{array}$ & \begin{tabular}{|c|}
$\infty$ \\
v \\
vi
\end{tabular} & $\begin{array}{l}\mid \\
a \\
6 \\
-\end{array}$ & \begin{tabular}{l|l}
8 & 7 \\
1 & 7 \\
-1 & 7
\end{tabular} & $\vec{\sim}$ & 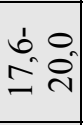 & & $\begin{array}{c}\infty \\
\tilde{n} \\
0\end{array}$ & $\begin{array}{l}N \\
\\
\sim\end{array}$ \\
\hline 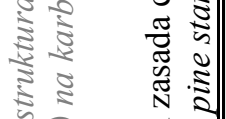 & 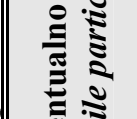 & a & $\begin{array}{l}1 n \\
n=\end{array}$ & $\begin{array}{l}\Omega \\
\sigma \\
\nabla\end{array}$ & $\left|\begin{array}{l}n \\
\hat{n} \\
n\end{array}\right|$ & $\begin{array}{l} \pm \\
0 \\
\pm\end{array}$ & 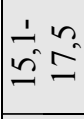 & $\vec{\sim}$ & $\begin{array}{ll}0 \\
0\end{array}$ & $\begin{array}{l}\infty \\
- \\
=\end{array}$ & $\begin{array}{cc}1 & 0 \\
& 0 \\
& 0 \\
& 0\end{array}$ & $\frac{n}{\infty}$ & $\begin{array}{c}n \\
2 \\
6 \\
-\end{array}$ & $\left|\begin{array}{c}\bar{n} \\
\infty \\
\sim\end{array}\right|$ & 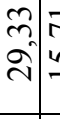 & $\begin{array}{l}F \\
n \\
n\end{array}$ & $\begin{array}{ll}1 & n \\
n & =\end{array}$ & & $\left|\begin{array}{l}n \\
\infty \\
1 \\
1\end{array}\right|$ & $\stackrel{9}{9}$ \\
\hline 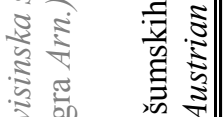 & 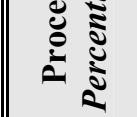 & $\infty$ & 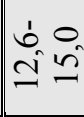 & $\vec{n}$ & $\mid \begin{array}{c}n \\
\infty \\
\infty\end{array}$ & $\begin{array}{l} \pm \\
0 \\
\pm\end{array}$ & 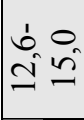 & $\begin{array}{l}2 \\
2 \\
a\end{array}$ & $\begin{array}{l}\bar{n} \\
n \\
n\end{array}$ & $\begin{array}{l}n \\
n \\
n\end{array}$ & 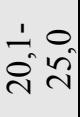 & $\begin{array}{l}m \\
\tilde{m} \\
\tilde{n}\end{array}$ & $\begin{array}{l}\infty \\
= \\
m\end{array}$ & \begin{tabular}{l|}
-6 \\
in \\
in
\end{tabular} & \begin{tabular}{l|l}
$\hat{\sigma}$ & $?$ \\
त̂ & 4
\end{tabular} & $\begin{array}{l}0 \\
\text { s. } \\
\text { ni }\end{array}$ & 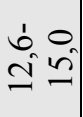 & & $\begin{array}{l}0 \\
\infty \\
\infty\end{array}$ & 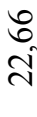 \\
\hline 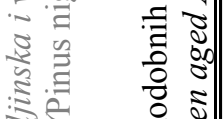 & & $r$ & 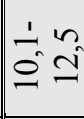 & $\begin{array}{l}2 \\
2 \\
2 \\
2\end{array}$ & $\left|\begin{array}{c}\infty \\
n \\
n \\
m\end{array}\right|$ & $\begin{array}{l}n \\
\tilde{n} \\
0\end{array}$ & 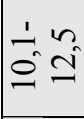 & $\mid \begin{array}{l}-1 \\
0 \\
-1\end{array}$ & 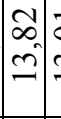 & $\begin{array}{l}\overline{0} \\
\text { वी }\end{array}$ & $\begin{array}{cc}1 & 0 \\
& 0 \\
-1 & 0\end{array}$ & $\begin{array}{l}\overrightarrow{\sigma_{n}} \\
\vec{\sim}\end{array}$ & \begin{tabular}{c}
0 \\
\multirow{2}{N}{} \\
N
\end{tabular} & $\mid \begin{array}{c}a \\
\dot{\sigma} \\
\sigma\end{array}$ & $\begin{array}{lll}8 & y \\
0 & \\
0 & & \end{array}$ & 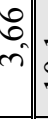 & $\begin{array}{cc}1 & n \\
0 & \simeq \\
0 & =\end{array}$ & $\left|\begin{array}{l}0 \\
6 \\
0 \\
-\end{array}\right|$ & $\begin{array}{l}\hat{n} \\
\hat{n} \\
\tilde{n}\end{array}$ & $\begin{array}{l}7 \\
\stackrel{7}{-}\end{array}$ \\
\hline 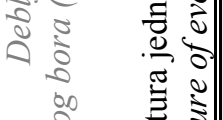 & & $\mid 0$ & $\begin{array}{ll}1 & 0 \\
0 & 0 \\
- & 0\end{array}$ & 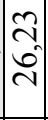 & 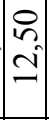 & $\bar{n}$ & $\mid \begin{array}{ll}1 & 0 \\
0 & 0 \\
- & 0\end{array}$ & $\begin{array}{l}\vec{\nabla} \\
\dot{\sigma} \\
\dot{\nabla}\end{array}$ & 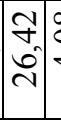 & $\begin{array}{l}\infty \\
0 \\
\forall \\
\forall\end{array}$ & $\begin{array}{ll}1 & 0 \\
0 & 0 \\
0 & n\end{array}$ & $\begin{array}{l}m \\
\hat{m} \\
\hat{m}\end{array}$ & 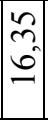 & \begin{tabular}{|l|}
$\infty$ \\
2 \\
$\sim$ \\
\end{tabular} & $\begin{array}{l}\hat{\sigma} \\
0 \\
0\end{array}$ & & $\begin{array}{cc}1 & 0 \\
0 & 0 \\
- & 0\end{array} \mid$ & \begin{tabular}{|l|} 
\pm \\
$\bar{m}$ \\
$m$
\end{tabular} & $\begin{array}{l}\hat{\infty} \\
\infty \\
\hat{\sim}\end{array}$ & $\begin{array}{l}\sim \\
\infty \\
\sim\end{array}$ \\
\hline 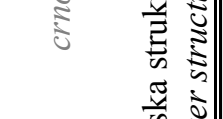 & & in & $\frac{n}{n}$ & $\begin{array}{l}n \\
\pm \\
\pm\end{array}$ & \begin{tabular}{|c|} 
\\
0 \\
0 \\
1
\end{tabular} & 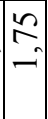 & $\frac{n}{n}$ & \begin{tabular}{|l|} 
\\
6 \\
0 \\
0 \\
v
\end{tabular} & \begin{tabular}{l|l}
$\tilde{n}$ & \multicolumn{1}{c}{} \\
$\tilde{n}$ & \\
$\hat{n}$ & \\
\end{tabular} & $\begin{array}{l}\text { ते } \\
\text { ปी }\end{array}$ & $\begin{array}{cc}1 & 0 \\
\sin & 0\end{array}$ & $\begin{array}{l}n \\
\infty \\
= \\
=\end{array}$ & $\begin{array}{l}P \\
\text { in }\end{array}$ & & $\begin{array}{l}8 \\
8 \\
+\end{array}$ & & $\frac{n}{i}$ & 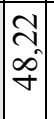 & $\begin{array}{c}0 \\
0 \\
0\end{array}$ & $\begin{array}{l}\text { in } \\
\text { in }\end{array}$ \\
\hline 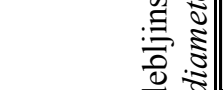 & & 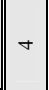 & 을 & & & & 으 & & & సે. & $8 \vec{n}$ & & & & & & 8 in & 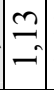 & $\begin{array}{l}1 \\
0\end{array}$ & \\
\hline 丞 & 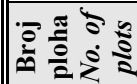 & $\| m$ & $\begin{array}{ll}\tilde{\pi} & \tilde{y} \\
\frac{\pi}{4} & \frac{3}{0}\end{array}$ & $\sim$ & -1 & $\sim$ & 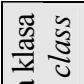 & $m$ & in & $a$ & 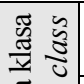 & $N$ & $n$ & in & $\mathrm{N}$ & + & 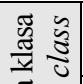 & in & $\infty$ & 6 \\
\hline 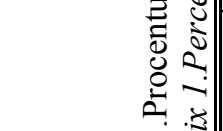 & 离 & $\| \sim$ & 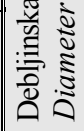 & $\begin{array}{l}\stackrel{0}{\mathbf{1}} \\
\stackrel{1}{二}\end{array}$ & 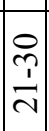 & $\frac{0}{\dot{y}}$ & 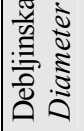 & 오 & 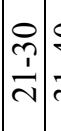 & $\begin{array}{c}\stackrel{0}{+} \\
\stackrel{1}{m} \\
m\end{array}$ & 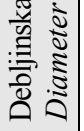 & $\mid \begin{array}{c}0 \\
\stackrel{n}{7} \\
7\end{array}$ & $\left|\begin{array}{l}8 \\
0 \\
1 \\
n\end{array}\right|$ & $\mid \begin{array}{c}0 \\
\frac{1}{6} \\
\end{array}$ & 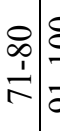 & \begin{tabular}{l||}
8 \\
$\frac{8}{1}$ \\
\\
\end{tabular} & 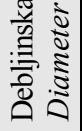 & 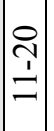 & 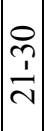 & $\frac{\text { f }}{m}$ \\
\hline $\begin{array}{ll}0 & 0 \\
0 & 0 \\
0 & \vdots \\
0 & 0\end{array}$ & 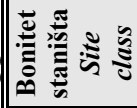 & - & & - & & & & & & & $=$ & & & & & & & ヨ & & \\
\hline
\end{tabular}




\begin{tabular}{|c|c|c|c|c|c|c|c|c|c|c|c|c|c|c|c|c|c|c|c|c|c|}
\hline$\stackrel{\circ}{\circ}$ & $\begin{array}{cc}1 & 0 \\
8 & 0 \\
8 & 0\end{array}$ & & & & & & $\begin{array}{ll}1 & 0 \\
i & n \\
n & n\end{array}$ & & & $\left|\begin{array}{cc}1 & 0 \\
\hdashline & 0 \\
8 & 0\end{array}\right|$ & & & & & & 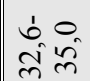 & & & \begin{tabular}{cc}
1 & 0 \\
\hdashline & 0 \\
8 & 0
\end{tabular} & & \\
\hline$\simeq$ & 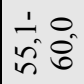 & & & & & & $\begin{array}{ll}1 & n \\
\dot{0} & \tilde{e} \\
n & 0\end{array}$ & & & 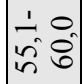 & & & & & & 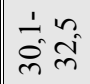 & & & $\begin{array}{ll}1 & 0 \\
& 0 \\
\text { in } & 8\end{array}$ & & \\
\hline \pm & 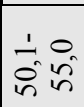 & & & & $\begin{array}{l}n \\
a \\
0\end{array}$ & $\begin{array}{l}\infty \\
2 \\
0\end{array}$ & $\mid \begin{array}{ll}1 & 0 \\
& 0 \\
\bar{N}\end{array}$ & & & \begin{tabular}{cc}
1 & 0 \\
\hdashline & $n$ \\
$n$ & $n$
\end{tabular} & & & & & & $\begin{array}{ll}1 & 0 \\
\tilde{N} & 0 \\
0\end{array}$ & & & \begin{tabular}{cc}
1 & 0 \\
\hdashline & 0 \\
$n$ & $n$ \\
$n$ & $n$
\end{tabular} & & \\
\hline 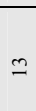 & $\begin{array}{cc}1 & 0 \\
7 & 0 \\
7 & 8\end{array}$ & & & & $\begin{array}{l}8 \\
8 \\
0\end{array}$ & 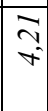 & $\begin{array}{cc}1 & n \\
& \sim \\
& 0\end{array}$ & & & \begin{tabular}{cc}
1 & 0 \\
\hdashline & 0 \\
7 & $n$
\end{tabular} \mid & & & & 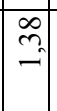 & & $\begin{array}{l}\dot{1} \tilde{n} \\
\tilde{n} \tilde{N}\end{array}$ & & & $\begin{array}{cc}1 & 0 \\
& 0 \\
f^{\prime} & 0\end{array}$ & $\vec{f}$ & \\
\hline$\simeq$ & $\begin{array}{cc}1 & 0 \\
\dot{0} & 8 \\
& 8\end{array}$ & & $\frac{1}{0}$ & $\begin{array}{c}\hat{\alpha} \\
-1 \\
-1\end{array}$ & $\begin{array}{l}0 \\
6 \\
\nabla\end{array}$ & $\begin{array}{l}\hat{n} \\
\infty\end{array}$ & 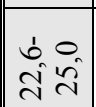 & \begin{tabular}{|l|} 
\\
0 \\
0
\end{tabular} & & $\left|\begin{array}{cc}1 & 0 \\
\hdashline & 0 \\
g & f\end{array}\right|$ & & & 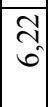 & \begin{tabular}{|l|}
$\infty$ \\
$n$ \\
n.
\end{tabular} & $\vec{n}$ & 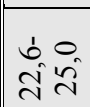 & & & \begin{tabular}{cc}
1 & 0 \\
\hdashline & 0 \\
$g$ & $f$
\end{tabular} & & $\begin{array}{l}8 \\
8\end{array}$ \\
\hline$=$ & $\begin{array}{ll}1 & 0 \\
n & 0 \\
m & 0\end{array}$ & 8 & $\frac{1}{0}$ & $\begin{array}{l}\infty \\
\infty \\
\sim\end{array}$ & $\begin{array}{l}0 \\
6 \\
0\end{array}$ & $\begin{array}{l}m \\
m\end{array}$ & $\mid \begin{array}{ll}\dot{1} & n \\
\dot{0} & \tilde{N}\end{array}$ & $\begin{array}{l}8 \\
0 \\
0\end{array}$ & \begin{tabular}{|l|}
$\infty$ \\
0 \\
$n$ \\
$n$
\end{tabular} & $\mid \begin{array}{cc}1 & 0 \\
& 0 \\
m & 0\end{array}$ & & & \begin{tabular}{l}
$a$ \\
\multirow{+}{c}{} \\
$i$
\end{tabular} & શે & $\stackrel{ }{\simeq}$ & 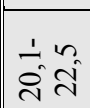 & & & $\begin{array}{cc}1 & 0 \\
& 0 \\
m & 9\end{array}$ & $=$ & $\begin{array}{l}8 \\
\infty\end{array}$ \\
\hline$\therefore$ & $\begin{array}{cc}1 & 0 \\
\dot{0} & \dot{n} \\
\tilde{n} & m\end{array}$ & $\begin{array}{l}8 \\
i \\
i\end{array}$ & $\begin{array}{l}0 \\
6 \\
m\end{array}$ & $\begin{array}{l}尺 \\
\cong \\
\approx\end{array}$ & $\begin{array}{l}\infty \\
\hat{N}\end{array}$ & $\begin{array}{l}2 \\
2 \\
2\end{array}$ & 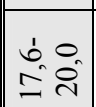 & $\begin{array}{l}0 \\
8 \\
i\end{array}$ & $\begin{array}{l}\vec{F} \\
\dot{m}\end{array}$ & $\mid$\begin{tabular}{cc}
1 & 0 \\
\hdashline & 0 \\
$\dot{m}^{2}$ & $m$
\end{tabular} & ơ & $\begin{array}{l}2 \\
\infty \\
0\end{array}$ & $\begin{array}{l}n \\
\tilde{n} \\
2\end{array}$ & 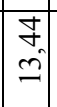 & 옹 & 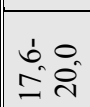 & กี & $\stackrel{n}{=}$ & $\mid$\begin{tabular}{cc}
1 & 0 \\
\hdashline & 0 \\
$\dot{e}$ & $n$
\end{tabular} & $\begin{array}{c}\tilde{n} \\
\infty \\
-0\end{array}$ & $\begin{array}{l}8 \\
\text { 건 }\end{array}$ \\
\hline$a$ & $\begin{array}{ll}1 & 0 \\
& 0 \\
7 & 0\end{array}$ & $\stackrel{-}{\mathrm{i}}$ & $\begin{array}{l}n \\
\stackrel{n}{v}\end{array}$ & $\begin{array}{l}n \\
\hat{\sim} \\
\end{array}$ & $\begin{array}{l}7 \\
z \\
2\end{array}$ & $\begin{array}{l}a \\
\vec{a} \\
\vec{z}\end{array}$ & 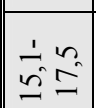 & \begin{tabular}{|l|}
$\vec{n}$ \\
0 \\
0 \\
-
\end{tabular} & $\begin{array}{l}0 \\
= \\
=\end{array}$ & $\mid \begin{array}{ll}1 & 0 \\
& 0 \\
& 0\end{array}$ & خे & $\begin{array}{l}\infty \\
\vdots \\
\vdots\end{array}$ & $\begin{array}{l} \\
\infty \\
\hat{\sim} \\
\end{array}$ & $\begin{array}{l}\mathrm{N} \\
\stackrel{2}{6} \\
\sim\end{array}$ & $\begin{array}{l} \\
0 \\
0 \\
0\end{array}$ & 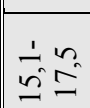 & & \begin{tabular}{l|}
2 \\
2 \\
2 \\
2
\end{tabular} & $\mid \begin{array}{cc}1 & 0 \\
& 0 \\
& 0 \\
0\end{array}$ & $\begin{array}{l}3 \\
2 \\
2\end{array}$ & $\begin{array}{l}8 \\
0 \\
0 \\
\end{array}$ \\
\hline$\infty$ & 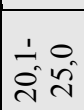 & 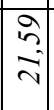 & $\mid \begin{array}{l}\overline{6} \\
\text { حi } \\
\end{array}$ & $\begin{array}{l}\mid \\
0 \\
\sim \\
\sim\end{array}$ & $\begin{array}{l}\hat{\sigma} \\
6 \\
-1\end{array}$ & 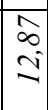 & 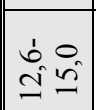 & 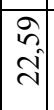 & \begin{tabular}{l|}
8 \\
0 \\
1 \\
\end{tabular} & 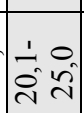 & \begin{tabular}{l|}
0 \\
\pm \\
\pm
\end{tabular} & \begin{tabular}{|c|}
0 \\
0 \\
$\tilde{2}$ \\
0
\end{tabular} & $\begin{array}{l}\tilde{n} \\
\tilde{n} \\
\tilde{n}\end{array}$ & $\begin{array}{l}\hat{b} \\
\Omega \\
-\end{array}$ & $\frac{n}{a}$ & $\begin{array}{ll}1 & 0 \\
\simeq & n \\
\simeq & 0\end{array}$ & $\begin{array}{l}= \\
= \\
=\end{array}$ & 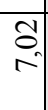 & 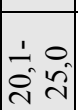 & \begin{tabular}{l|}
$\vec{\infty}$ \\
\pm \\
\pm
\end{tabular} & \begin{tabular}{|l}
8 \\
$\infty$ \\
\end{tabular} \\
\hline r & $\begin{array}{ll}1 & 0 \\
- & 0\end{array}$ & \begin{tabular}{l|}
$\overline{\widehat{a}}$ \\
$\infty$ \\
$\sim$ \\
$\sim$
\end{tabular} & $\begin{array}{l}\overline{1} \\
\infty \\
\sim\end{array}$ & 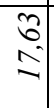 & $\begin{array}{l} \\
n \\
n\end{array}$ & $\begin{array}{l}\infty \\
0 \\
n \\
n\end{array}$ & $\begin{array}{l}\dot{1} \\
\ddot{0} \simeq \\
0\end{array}$ & 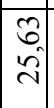 & \begin{tabular}{|l|}
$\infty$ \\
0 \\
0 \\
0 \\
\end{tabular} & 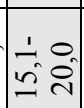 & \begin{tabular}{|l|} 
\\
$\infty$ \\
0 \\
$m$
\end{tabular} & $\begin{array}{l} \pm \\
0 \\
n \\
m\end{array}$ & $\begin{array}{l}\stackrel{\nabla}{\sim} \\
\stackrel{2}{\sim}\end{array}$ & $\begin{array}{c}0 \\
+ \\
0 \\
-1 \\
-1\end{array}$ & $\bar{n}$ & 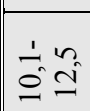 & $\begin{array}{l}3 \hat{6} \\
\hat{2} \\
\end{array}$ & 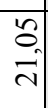 & $\mid \begin{array}{cc}1 & 0 \\
& 0 \\
-1 & 0\end{array}$ & $=$ & \begin{tabular}{|c|} 
\\
\\
$\infty$ \\
$\infty$
\end{tabular} \\
\hline 0 & $\begin{array}{cc}1 & 0 \\
0 & 0 \\
0 & 0\end{array}$ & $\left|\begin{array}{l}\nabla \\
\infty \\
-\infty\end{array}\right|$ & $\begin{array}{l}a \\
2 \\
\text { iे }\end{array}$ & $\begin{array}{l}5 \\
\infty \\
n\end{array}$ & $\begin{array}{l}3 \\
\sigma \\
\sigma\end{array}$ & $\stackrel{m}{=}$ & $\begin{array}{l}0 \\
0 \\
1 \\
b \\
i\end{array}$ & 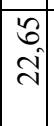 & $\begin{array}{l}\vec{b} \\
0 \\
-\end{array}$ & $\mid \begin{array}{cc}1 & 0 \\
0 & 0 \\
0 & 0\end{array}$ & $\begin{array}{l}\tilde{J} \\
\tilde{n}\end{array}$ & $\frac{\tilde{\sigma}}{\tilde{\sigma}}$ & $\begin{array}{l}\hat{6} \\
n\end{array}$ & $\frac{n}{6}$ & $\stackrel{ }{\simeq}$ & $\begin{array}{l}0 \\
0 \\
\vdots \\
0 \\
0\end{array}$ & $\begin{array}{l}8 \\
8 \\
2\end{array}$ & $\begin{array}{l}\exists \\
\stackrel{f}{f}\end{array}$ & $\begin{array}{ll}1 & 0 \\
0 & 0\end{array}$ & $\vec{\sigma}$ & $\begin{array}{l}8 \\
\pm\end{array}$ \\
\hline in & $\begin{array}{l}0 \\
0 \\
1 \\
n \\
n\end{array}$ & $\begin{array}{l}2 \\
\text { जे } \\
\text { - }\end{array}$ & $\begin{array}{l}3 \\
= \\
=\end{array}$ & 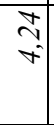 & $\begin{array}{l}\stackrel{R}{m} \\
m\end{array}$ & & $\frac{n}{\frac{n}{n}}$ & \begin{tabular}{l|} 
\\
\pm \\
\pm
\end{tabular} & \begin{tabular}{l|}
0 \\
\\
0 \\
0
\end{tabular} & $\begin{array}{l}0 \\
0 \\
1 \\
n\end{array}$ & $\begin{array}{l}\sim \\
\sim \\
n\end{array}$ & Fे & $\stackrel{0}{2}$ & $\begin{array}{l}\hat{\alpha} \\
\text { mे }\end{array}$ & & $\frac{n}{n}$ & \begin{tabular}{|l|}
$\tilde{\alpha}$ \\
$\infty$ \\
$\infty$
\end{tabular} & 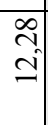 & $\begin{array}{c}0 \\
0 \\
1 \\
n\end{array}$ & & \\
\hline 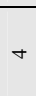 & $\begin{array}{l}\vec{n} \\
0 \\
0\end{array}$ & & & & & & $\begin{array}{l}\overrightarrow{1} \\
0 \\
0\end{array}$ & $\overrightarrow{\mid \overrightarrow{0}}$ & & $\begin{array}{l}\overrightarrow{1} \\
0 \\
0\end{array}$ & & & & & & $\begin{array}{l}\overrightarrow{1} \\
0 \\
0\end{array}$ & & & $\begin{array}{l}\vec{n} \\
0 \\
0\end{array}$ & & \\
\hline m & 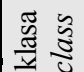 & $\pi$ & $\simeq$ & $m$ & $m$ & $\nabla$ & 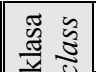 & $=$ & $\sim$ & 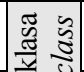 & 6 & $\sim$ & $m$ & $m$ & - & 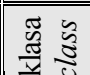 & -1 & -1 & 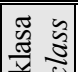 & - & - \\
\hline N & 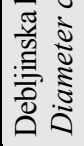 & $\mid \begin{array}{c}0 \\
\stackrel{n}{1} \\
7 \\
\end{array}$ & $\left|\begin{array}{c}8 \\
0 \\
1 \\
\end{array}\right|$ & $\frac{9}{\frac{1}{6}}$ & $\begin{array}{c}0 \\
\infty \\
1 \\
\end{array}$ & $\begin{array}{l}\frac{8}{a} \\
\frac{1}{\infty}\end{array}$ & 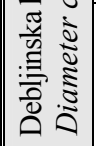 & 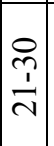 & 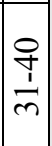 & 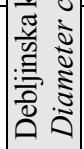 & $\begin{array}{c}0 \\
\sim \\
1 \\
7 \\
\end{array}$ & $\mid \begin{array}{l}0 \\
0 \\
1 \\
\bar{n}\end{array}$ & $\begin{array}{l}0 \\
\frac{1}{6} \\
\end{array}$ & 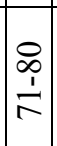 & $\frac{8}{\infty}$ & 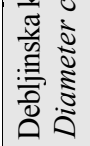 & $\begin{array}{c}0 \\
\stackrel{1}{1} \\
\vec{N}\end{array}$ & 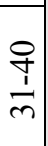 & 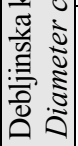 & $\frac{0}{2}$ & $\frac{8}{\infty}$ \\
\hline- & & & $\Xi$ & & & & & & & $z$ & & & & & & & & & & & \\
\hline
\end{tabular}




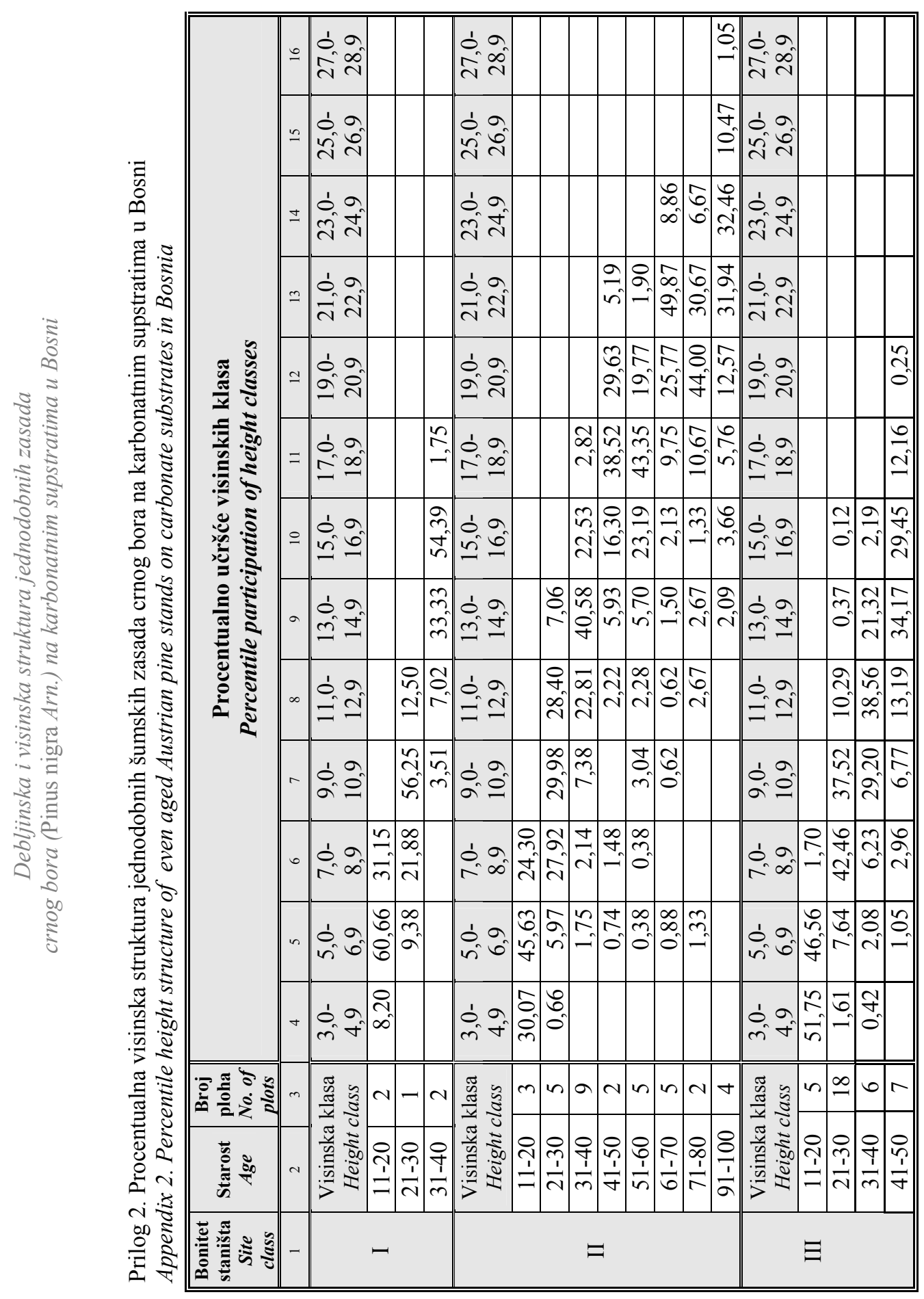




\begin{tabular}{|c|c|c|c|c|c|c|c|c|c|c|c|c|c|c|c|c|c|}
\hline$\simeq$ & & & & \begin{tabular}{|l|}
\multirow{2}{*}{} \\
$\dot{\sigma}_{0}$
\end{tabular} & $\left|\begin{array}{cc}0 & a \\
\tilde{N} & \infty \\
\sim & 0\end{array}\right|$ & & & & & & & & $\left|\begin{array}{cc}0 & \sigma \\
\hat{N} & \infty \\
\tilde{v} & \sqrt[v]{ }\end{array}\right|$ & & & & \\
\hline$\simeq$ & & & & 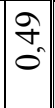 & 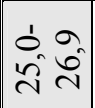 & & & & & & & & $\left|\begin{array}{cc}1 & \sigma \\
0 & \hat{\sigma} \\
& \sqrt{n}\end{array}\right|$ & & & & \\
\hline \pm & & $\begin{array}{l}0 \\
0 \\
0\end{array}$ & & \begin{tabular}{l|}
$n$ \\
0 \\
$n$ \\
$n$
\end{tabular} & $\begin{array}{ll}\dot{1} & \sigma \\
\tilde{\lambda} & \dot{\sim}\end{array}$ & & & & & & & & 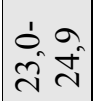 & & & & \\
\hline$\cong$ & & 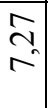 & $\begin{array}{c}m \\
m \\
\infty\end{array}$ & 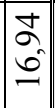 & $\begin{array}{cc}1 & a \\
\vec{v} & \tilde{v}\end{array} \mid$ & & & & & & & 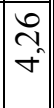 & $\left|\begin{array}{cc}0 & a \\
\bar{i} & \tilde{v}\end{array}\right|$ & & & & \\
\hline$\simeq$ & $\begin{array}{l}m \\
\pi\end{array}$ & $\begin{array}{l}\sim \\
\tilde{n} \\
\infty \\
\sim \\
\sim\end{array}$ & $\begin{array}{l}\nexists_{\infty} \\
f^{\prime}\end{array}$ & $\begin{array}{l}\hat{\alpha} \\
\hat{n}\end{array}$ & $\begin{array}{ll}0 & \sigma \\
\hat{a} & \tilde{\nu}\end{array}$ & & & & & & 吾 & $\overrightarrow{\bar{\sigma}}$ & $\left|\begin{array}{ll}1 & a \\
a & 0 \\
0 & 0\end{array}\right|$ & & & $\begin{array}{l}\stackrel{R}{r} \\
m\end{array}$ & $\begin{array}{l}8 \\
0 \\
6\end{array}$ \\
\hline$=$ & 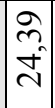 & 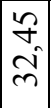 & $\frac{n}{2}$ & 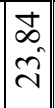 & 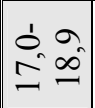 & & & & $\begin{array}{l}\hat{\lambda} \\
\tilde{\sigma}\end{array}$ & 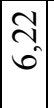 & \begin{tabular}{l}
\multirow{2}{n}{} \\
$\tilde{N}$
\end{tabular} & \begin{tabular}{|l|} 
\\
$\overline{6}$ \\
$n$
\end{tabular} & 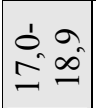 & & & & $\begin{array}{l}8 \\
\text { ¿ } \\
\text { ¿ }\end{array}$ \\
\hline 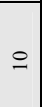 & 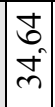 & $\frac{\infty}{a}$ & $\begin{array}{l}0 \\
2 \\
\text { in }\end{array}$ & \begin{tabular}{|l|}
\multirow{2}{*}{} \\
గ్
\end{tabular} & $\begin{array}{cc}0 & \hat{\sigma} \\
n & 0\end{array}$ & & & $\begin{array}{l}\infty \\
\infty \\
0\end{array}$ & $\begin{array}{l}\tilde{2} \\
\tilde{m} \\
\tilde{m}\end{array}$ & \begin{tabular}{|c|}
$\hat{N}$ \\
$\infty$ \\
$n$ \\
$n$
\end{tabular} & 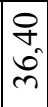 & \begin{tabular}{|l|}
2 \\
$\infty$ \\
\pm \\
-
\end{tabular} & $\left|\begin{array}{cc}0 & \hat{\sigma} \\
n & 0\end{array}\right|$ & & & \begin{tabular}{l|}
$\vec{\infty}$ \\
$\dot{ \pm}$ \\
\end{tabular} & $\begin{array}{l}8 \\
8 \\
\pm\end{array}$ \\
\hline$a$ & $\begin{array}{l}0 \\
6 \\
-0 \\
0\end{array}$ & $\begin{array}{l}\hat{6} \\
6\end{array}$ & \begin{tabular}{|l|}
$\infty$ \\
$i$ \\
$i$
\end{tabular} & \begin{tabular}{l|}
8 \\
8 \\
$m$
\end{tabular} & $\begin{array}{cc}0 & \sigma \\
\tilde{c} & \pm\end{array} \mid$ & & $\begin{array}{l}n \\
n \\
f \\
\end{array}$ & $\begin{array}{l}n \\
2 \\
\infty \\
-\end{array}$ & $\begin{array}{l} \\
0 \\
n \\
m\end{array}$ & $\begin{array}{l}n \\
n \\
n \\
n\end{array}$ & 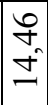 & $\mid$\begin{tabular}{|c|}
$\infty$ \\
m \\
0 \\
0
\end{tabular} & $\left|\begin{array}{ll}0 & a \\
n & \Xi\end{array}\right|$ & & & $\exists=$ & $\begin{array}{l}8 \\
0 \\
0\end{array}$ \\
\hline$\infty$ & 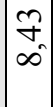 & & $\begin{array}{l}\tilde{\alpha} \\
\hat{\sigma}\end{array}$ & $\begin{array}{l}\tilde{2} \\
\tilde{m}\end{array} \mid$ & $\begin{array}{ll}1 & \sigma \\
= & c\end{array}$ & $\begin{array}{l}\infty \\
0 \\
0 \\
0\end{array}$ & $\begin{array}{l}\hat{n} \\
\tilde{n}\end{array}$ & $\begin{array}{l}a \\
0 \\
n \\
n\end{array}$ & $\begin{array}{l}\stackrel{0}{+} \\
\dot{t} \\
\sigma\end{array}$ & $\mid \begin{array}{l}n \\
n \\
n \\
\end{array}$ & $=$ & \begin{tabular}{l|}
$\stackrel{0}{2}$ \\
$\sim$ \\
$\forall$
\end{tabular} & 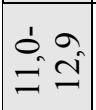 & & & $\begin{array}{l}n \\
\infty \\
n \\
n\end{array}$ & $\begin{array}{l}8 \\
8 \\
\pm\end{array}$ \\
\hline- & $\begin{array}{l}\infty \\
0 \\
n \\
n\end{array}$ & $\begin{array}{l}0 \\
2 \\
\text { in }\end{array}$ & $\begin{array}{l}m \\
\hat{\sigma} \\
\end{array}$ & $\mid \begin{array}{l}J_{0} \\
0\end{array}$ & $\begin{array}{ll}1 & \hat{\sigma} \\
a & 0\end{array}$ & $\begin{array}{l}\infty \\
\vdots \\
= \\
=\end{array}$ & $\begin{array}{l}n \\
2 \\
n \\
n\end{array}$ & $\begin{array}{l}\vec{\sigma} \\
- \\
-\end{array}$ & $\begin{array}{c}\stackrel{0}{+} \\
\dot{+} \\
\sigma\end{array}$ & $\left|\begin{array}{c}n \\
\hat{b} \\
\text { i }\end{array}\right|$ & $\begin{array}{l}0 \\
\sim \\
\forall\end{array}$ & \begin{tabular}{|l|}
$m$ \\
$i$
\end{tabular} & $\left|\begin{array}{ll}1 & a \\
0 & 0 \\
a & 0\end{array}\right|$ & $\left|\begin{array}{l}\infty \\
0 \\
\tilde{2} \\
\hat{2}\end{array}\right|$ & $\begin{array}{l}n \\
0 \\
\bar{n} \\
\end{array}$ & $\begin{array}{l}\vec{\infty} \\
\pm \\
\pm\end{array}$ & $\begin{array}{l}8 \\
0 \\
0\end{array}$ \\
\hline 0 & $\mid$ & \begin{tabular}{|l|} 
\\
$\sim$ \\
in \\
\end{tabular} & $\begin{array}{l}\tilde{\sigma} \\
\hat{\sigma}\end{array}$ & & 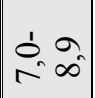 & 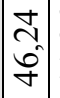 & $\begin{array}{l}0 \\
= \\
= \\
=\end{array}$ & \begin{tabular}{|c|}
$n$ \\
$\hat{n}$ \\
6
\end{tabular} & $\approx$ & $\begin{array}{l}\infty \\
\infty \\
0 \\
0\end{array}$ & $\frac{0}{7}$ & & $\mid \begin{array}{cc}1 & \sigma \\
- & \infty\end{array}$ & 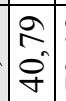 & $\frac{\infty}{2}$ & $\begin{array}{l}\stackrel{R}{r} \\
m\end{array}$ & $\begin{array}{l}8 \\
0 \\
0\end{array}$ \\
\hline in & $\mid \begin{array}{l}0 \\
6 \\
0 \\
0\end{array}$ & & $\begin{array}{l}0 \\
n \\
n\end{array}$ & & $\begin{array}{ll}1 & \sigma \\
i & 0\end{array}$ & $\begin{array}{l}m \\
\tilde{n} \\
\tilde{m}\end{array}$ & \begin{tabular}{|l|}
$n$ \\
$n$ \\
$\nabla$ \\
\end{tabular} & $\begin{array}{l}\infty \\
\infty \\
0\end{array}$ & $\begin{array}{l}n \\
\infty \\
0 \\
0\end{array}$ & & n & & $\begin{array}{ll}1 & a \\
n & 0\end{array}$ & $\begin{array}{l}n \\
n \\
n \\
n\end{array}$ & $\hat{N}$ & & \\
\hline+ & $\frac{7}{0}$ & $\begin{array}{l}\dot{a} \\
\sigma \\
0\end{array}$ & & & $\begin{array}{ll}1 & \sigma \\
m & \gamma\end{array}$ & $\begin{array}{l}0 \\
8 \\
\text { î }\end{array}$ & & & & & & & $\left|\begin{array}{ll}1 & \sigma \\
m & \nabla\end{array}\right|$ & & & & \\
\hline$m$ & $\simeq$ & $m$ & $m$ & $\nabla$ & $\mid \begin{array}{ll}\pi & \tilde{z} \\
\tilde{z} & \vdots\end{array}$ & $=$ & $\sim$ & 0 & $\sim$ & $m$ & $m$ & - & $\tilde{z} \tilde{z}$ & -1 & - & - & - \\
\hline$\sim$ & $\left|\begin{array}{l}0 \\
0 \\
1 \\
1 \\
n\end{array}\right|$ & 움 & $\mid \begin{array}{l}\infty \\
\infty \\
1 \\
1\end{array}$ & $\frac{8}{i}$ & 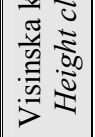 & D & 守 & 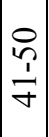 & $\begin{array}{l}0 \\
0 \\
1 \\
n\end{array} \mid$ & 움 & $\begin{array}{l}\infty \\
\infty \\
1 \\
\end{array}$ & $\mid \begin{array}{c}8 \\
\frac{1}{1} \\
\infty\end{array}$ & 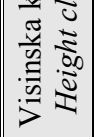 & 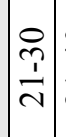 & $\frac{\text { P }}{\stackrel{1}{r}}$ & $\begin{array}{l}\stackrel{R}{1} \\
\frac{1}{6}\end{array}$ & $\frac{8}{1}$ \\
\hline- & \multicolumn{4}{|c|}{$\Xi$} & \multicolumn{8}{|c|}{$\geq$} & \multicolumn{5}{|c|}{$>$} \\
\hline
\end{tabular}

